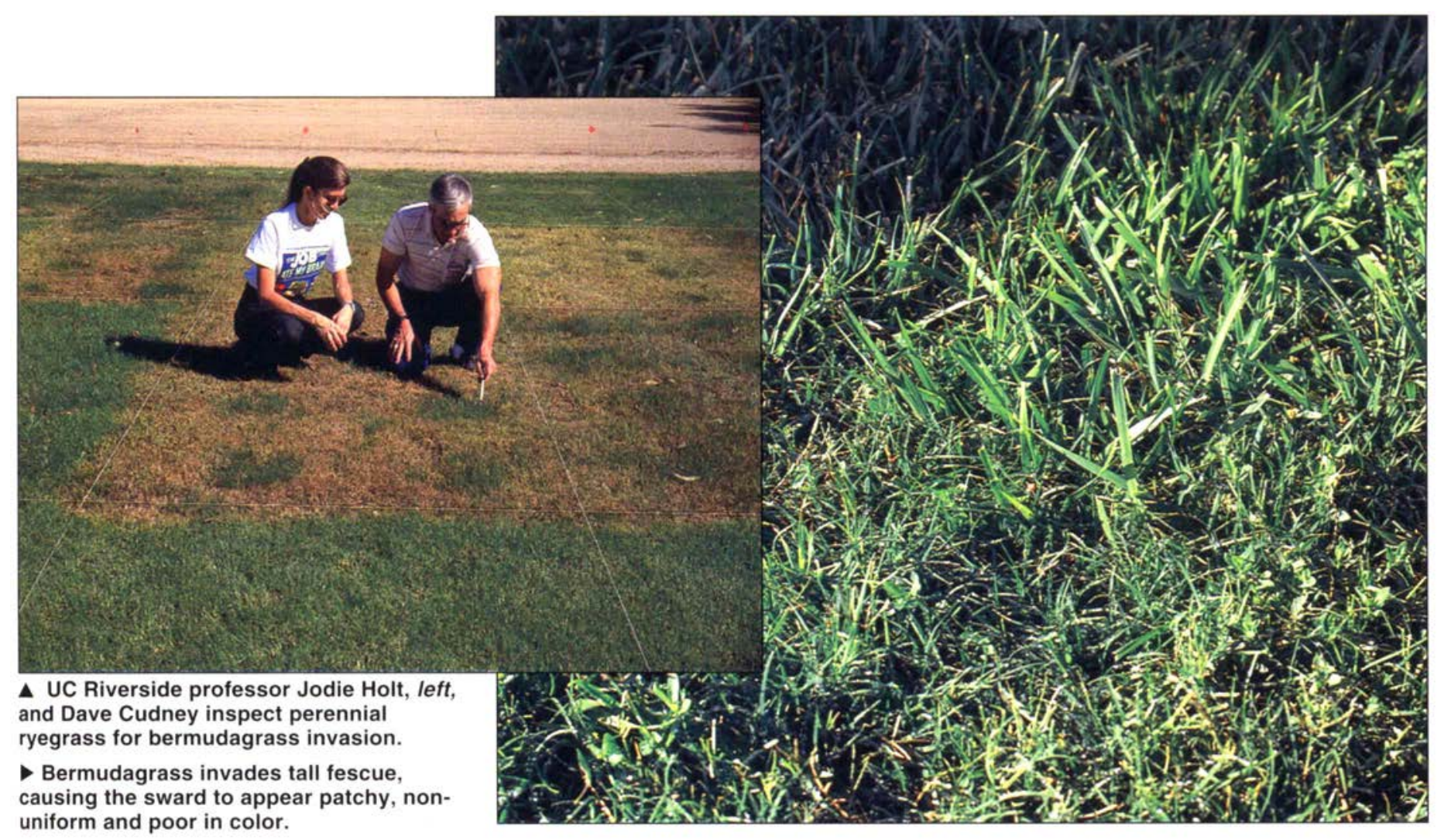

\title{
Sequential herbicide sprays control bermudagrass in cool-season turf
}

David W. Cudney a Clyde L. Elmore a Victor A. Gibeault $\square$ Bill Krueger $\square$ Steve Reints

\begin{abstract}
Common bermudagrass is an invasive perennial weed of coolseason turfgrass in California. Complete renovation and loss of use of the turf for up to 4 months has been the only practical method of restoring desirable cool-season turfgrasses. In studies in Southern and Northern California, common bermudagrass was suppressed with sequential herbicide applications, allowing seedling establishment and regrowth of competitive coolseason turfgrass species. This was accomplished without losing use of the turf area.
\end{abstract}

Common bermudagrass can be either a desirable turfgrass species or an aggressive perennial weed. This is particularly true in California's warm, temperate climates, where common bermudagrass is well adapted and can rapidly invade cool-season turfgrass swards of perennial ryegrass and tall fescue. Areas that have been invaded by common bermudagrass tend to have poor color and a patchy, nonuniform appearance, particularly when dormant during the winter months. Current renovation procedures for the removal of common-bermudagrassinfested areas are to fumigate or to treat with glyphosate and replant with competitive, cool-season species (perennial ryegrass or tall fescue). Both methods require the loss of use of the turfgrass area for several weeks or months while the desired cool-season species is reestablished. Common bermudagrass (Cynodon dactylon) usually reinvades within a few years, even when management techniques are used to promote the competitiveness of the desired cool-season species (proper mowing height, fertility and irrigation).

Recent work with kikuyugrass (Pennisetum clandestinum) infestations in cool-season turf has demonstrated that sequential applications of herbicides can limit kikuyugrass and allow recovery and reestablishment of coolseason turfgrass species, including perennial ryegrass and tall fescue. Sequential applications of fenoxaprop have been used in the southeastern states to reduce common bermudagrass infestations in tall fescue. Sequential applications of triclopyr were shown to reduce growth of common bermudagrass and kikuyugrass in California.

Both fenoxaprop and triclopyr can be used selectively in established coolseason turfgrass. However, some loss of stand and stunting has been reported 
in newly seeded perennial ryegrass and tall fescue. In reclaiming turf areas with a high percentage of common bermudagrass in the stand, reseeding of perennial ryegrass or tall fescue may be necessary during the reclamation process to fill the voids vacated by the common bermudagrass. Therefore an evaluation of when applications of these herbicides would be less detrimental to tall fescue or perennial ryegrass seedlings would be helpful.

The objectives of the studies discussed here were to evaluate the use of sequential applications of fenoxaprop and triclopyr alone and in combination for common bermudagrass control, and to evaluate the safety of these herbicides for perennial ryegrass and tall fescue germination, seedling growth and establishment.

\section{Field and greenhouse trials}

We conducted two field experiments, each lasting 2 years, and two greenhouse herbicide-tolerance studies. The field experiments were located at Riverside and at Willows in the northern Sacramento Valley. The plot areas were always well maintained with adequate fertility and moisture and mowed to a height of approximately 1.5 to 2.0 inches. The greenhouse studies were conducted at the UC Riverside Experiment Station. Herbicide treatments in both the field experiments and the greenhouse experiments were made with a $\mathrm{CO}_{2}$-pressurized backpack sprayer calibrated to deliver 30 gallons per acre of spray mixture at a pressure of 30 psi. Irrigation was withheld from the treated areas for 24 hours after each herbicide treatment. All experiments were arranged in randomized complete-block designs. The Riverside field experiment was replicated six times; the Willows and greenhouse experiments were replicated four times.

Riverside field experiment. The experiment consisted of a single yearly application compared to sequential applications of fenoxaprop and triclopyr applied at both high and low rates. In addition, the herbicides were combined at both the high and low rates. The plots were established on the Experiment Station in a 6-year-old stand of common bermudagrass ('Arizona common').

On June 15, 1992, the common bermudagrass sod was "scalped" to a height of 0.4 inch, the resulting debris was removed and then perennial ryegrass ('Manhattan $\mathrm{II}^{\prime}$ ) was uniformly broadcast seeded by hand in each replication with preweighed amounts of seed at a rate of $10 \mathrm{lb} /$ $1,000 \mathrm{ft}^{2}$. The plot area was watered twice daily for 3 days, then watered daily for the next 5 days. Thereafter we used an irrigation regime normal to perennial ryegrass turfgrass maintenance (0.5-inch irrigation at 2-day intervals in the summer months). Triclopyr ( 0.5 and $1.0 \mathrm{lb} / \mathrm{acre})$ and fenoxaprop ( 0.19 and $0.38 \mathrm{lb} /$ acre) were applied alone and in two combinations of triclopyr and fenoxaprop $(0.5+0.19 \mathrm{lb} /$ acre and $1.0+0.38 \mathrm{lb} /$ acre) as a single application and as four sequential applications each year. The single application and the first of the sequential applications were made on July 2, 1992, at the two-leaf stage for perennial ryegrass. Sequential applications were made when common bermudagrass regrowth was evident, which was at 4-to-6-week intervals (Aug. 11, Sept. 18 and Oct. 20). In 1993 the single and first sequential application was made on June 1, followed by sequential applications on July 12 ,

Aug. 24 and Oct. 5. Percent cover of common bermudagrass was visually estimated at the end of the growing season.

Willows field experiment. The Willows field experiment was conducted in a mixed sward of tall fescue ('Bonsai') that was being invaded by common bermudagrass. At the time that treatment was initiated common bermudagrass averaged $55 \%$ of the sward. We used the same rates of fenoxaprop and triclopyr as used for the Riverside experiment, except that the single-treatment option was eliminated. Sequential herbicide treatments were made as the effect of the previous application declined, with retreatments within 4-to-8-week intervals. Applications were made on May
18, July 18, Aug. 29 and Sept. 30 in 1994 and on June 14, July 21, Sept. 18 and Oct. 18 in 1995. Common bermudagrass cover was estimated visually at the end of each common bermudagrass growing season (Nov. 18, 1994, and Nov. 16, 1995).

Greenhouse experiments. In the two greenhouse experiments, we compared two cool-season turfgrass species, herbicides and turfgrass stage at treatment. The experiments were established in Riverside on Nov. 14, 1995, and Jan. 17, 1996. Pots 8 inches in diameter and 8 inches deep were filled to within 2 inches of their tops with a mixture of $50 \%$ sand, $25 \%$ vermiculite and $25 \%$ peat. To simulate field soilsurface conditions, 1 inch of a silt loam soil with less than $1 \%$ organic matter was deposited over the surface of each pot. The pots were uniformly seeded with 300 seeds of tall fescue ('Bonsai') or perennial ryegrass ('Manhattan II'). A 0.25 -inch layer of the same field soil was applied over the grass seed. Pots were irrigated daily during germination, then three times weekly after grass establishment. Fenoxaprop at $0.38 \mathrm{lb} /$ acre, triclopyr at $1.0 \mathrm{lb} /$ acre and a combination of both at 0.38 and $1.0 \mathrm{lb} /$ acre were applied either preemergence (PRE) or postemergence (POST) at the one- and two-leaf stages of the grasses. The number of plants in each pot was recorded 6 weeks after treatment. Data for plants per pot were converted to percent relative to the untreated pots for each treatment stage; this allowed normalization of plant survival data from the three stages for statistical comparison purposes. There were no significant differences in the grass response between years; therefore data was combined from both experiments.

\section{Single sprays ineffective}

Riverside field experiment. Neither herbicide controlled common bermudagrass when applied alone or in combination as a single treatment per year (fig. 1). Sequential herbicide applications reduced bermudagrass cover. After 2 years with four sequential treatments each year, common bermudagrass cover with fenoxaprop, 
triclopyr and the combination treatment was $11 \%, 4 \%$ and $3 \%$, respectively. When no herbicide was used, common bermudagrass cover was $89 \%$.

Fenoxaprop caused perennial ryegrass to yellow slightly, which persisted until the next mowing. This injury was transient and recovery was rapid and complete. Perennial ryegrass tillers completely filled in the space relinquished by the declining bermudagrass population; perennial ryegrass percent cover was directly proportional to the common bermudagrass cover and was near $100 \%$ of the stand for the best herbicide treatments by the end of the experiment.

Willows experiment. Common bermudagrass cover was reduced at the end of the first growing season (Oct. 24, 1994) for all herbicide treatments (fig. 2.). All treatments also reduced common bermudagrass cover in 1995 after 2 years of treatment.

Triclopyr was not as effective as fenoxaprop or the combination treatment ( $28 \%$ compared to $8 \%$ for common bermudagrass cover).

As in the Riverside experiment, as the percentage of common bermudagrass was reduced, the tall fescue stand became dominant. No phytotoxic effect on the established tall fescue was noted for any of the herbicide treatments.

Greenhouse experiments. The response of tall fescue and perennial ryegrass was similar for treatment. stage and herbicides when the effects on plant survival are compared. When averaged across turfgrass species and treatment stage, plant survival was lowest for fenoxaprop (64\%) and the combination treatments $(66 \%)$ compared to triclopyr (77\%). Plant survival was lowest for the PRE treatments $(59 \%)$, followed by treatments at the one-leaf stage $(69 \%)$ and the two-leaf stage $(79 \%)$, when the overall means for treatment stage are compared. Among individual means for treatment and stage of application (fig. 3), the lowest survival ratios were for fenoxaprop and the combination applied PRE to perennial ryegrass ( $43 \%$ and $47 \%$, respectively, of the untreated pots). Tall fescue was also reduced by PRE treat- ments of fenoxaprop and the combination $(62 \%$ and $68 \%$ survival, respectively, of the untreated plots). Fenoxaprop and the combination applied at the one-leaf stage also reduced stand, particularly in the perennial ryegrass pots (44\% and $51 \%$ survival, respectively). When averaged across turfgrass species, survival was highest for the triclopyr plots applied at the oneleaf stage $(80 \%)$ and the two-leaf stage $(77 \%)$ and for the fenoxaprop treatment at the two-leaf stage (87\%).

In a reseeding program with subsequent sequential herbicide application, as practiced in the Riverside experiment, emerging and newly emerged grass seedlings could get sprayed with herbicides. Under these conditions, application should be delayed until most of the emerging turfgrass is at the two-leaf stage, particularly when fenoxaprop is used with perennial ryegrass.

\section{Bermudagrass management}

The results of this research can be integrated into a management program where tall fescue or perennial ryegrass is being invaded by common bermudagrass. Fenoxaprop, triclopyr or a combination of the two can be used in sequential applications to suppress common bermudagrass, allowing recovery of the desirable coolseason species. Fenoxaprop was more effective than triclopyr in reducing common bermudagrass; however, it was also more injurious to the newly seeded perennial ryegrass. The combination of the two herbicides offers the advantage of controlling additional weeds, both grass and broad-leaved species. Sequential applications were required over a 2-year period for control of common bermudagrass in these studies, although considerable progress was made in the first year, particularly at Riverside. It is probable that after initial success with this method, retreatments would be required in succeeding years as common bermudagrass would continue to reinvade. Employing proper cultural techniques (optimum mowing height, soil fertility and irrigation for cool-season species) could slow reinvasion.

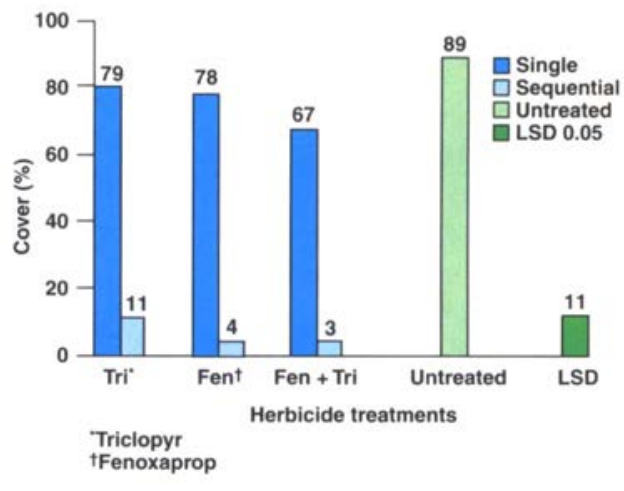

Fig. 1. Effects of single and sequential herbicide applications over 2 years on percent bermudagrass cover, Riverside.

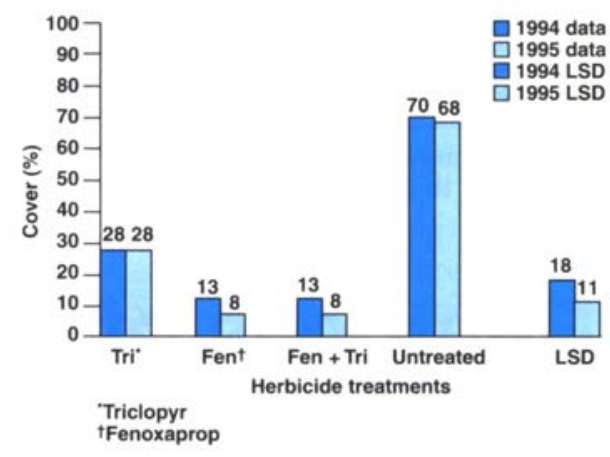

Fig. 2. Effects of single and sequential herbicide applications over 2 years on percent bermudagrass cover, Willows.

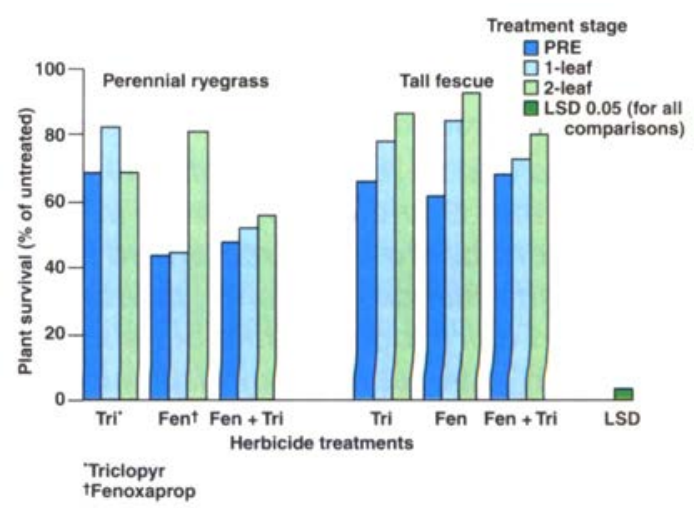

Fig. 3. Perennial ryegrass and tall fescue plant survival as affected by herbicide treatment and growth stage.

D.W. Cudney is Extension Weed Scientist, V.A. Gibeault is Extension Environmental Horticulturist and S. Reints is Staff Research Associate, Department of Botany and Plant Sciences, UC Riverside, C.L. Elmore is Extension Weed Scientist, Department of Vegetable Crops, UC Davis; and B. Krueger is Farm Advisor/ County Director, UCCE, Glenn County. 